\title{
A new nephelometric assay for $\beta$-trace protein (prostaglandin D synthase) as an indicator of liquorrhoea
}

\author{
H F Petereit, G Bachmann, M Nekic, H Althaus, R Pukrop
}

\begin{abstract}
Objectives-To determine the sensitivity and specificity of a nephelometric $\beta$-trace protein assay for the diagnosis of liquorrhoea.

Methods-One hundred and forty clinical samples with suspected liquorrhoea were analysed by a newly developed nephelometric assay. An established electroimmunoassay served as a reference method. The sensitivity and specificity of the $\beta$-trace nephelometric assay were calculated by a $2 \times 2$ contingency table for 10 different versions of a dichotomised nephelometric variable. In 52 patients (79 samples), the nephelometric findings were validated by referring to the clinical diagnosis based on the course of the disease, imaging techniques, and surgical inspection.

Results-Given a specificity of $100 \%$, a $\beta$-trace protein concentration of $6 \mathrm{mg} / 1$ or higher in a sample indicated liquorrhoea with a sensitivity of $92 \%$ compared with the reference method and of $93 \%$ compared with the clinical evaluation. The relation between the electroimmunoassay and the nephelometric assay was highly significant $(p<0.001)$.

Conclusions-The nephelometric $\beta$-trace protein assay is a simple and rapid method for the detection of liquorrhoea with high sensitivity and specificity and may facilitate the diagnosis of fistulas leaking CSF.
\end{abstract}

(F Neurol Neurosurg Psychiatry 2001;71:347-351)

für Neurologie und

Psychiatrie,

Josef-Stelzmann-

Strasse 9, D-50924

Köln, Germany

H F Petereit

$\mathrm{M}$ Nekic

R Pukrop

Department of

Otolaryngology,

University of Cologne

G Bachmann

Dade Behring Marburg GmbH, Germany

$\mathrm{H}$ Althaus

Correspondence to: Dr H-F Petereit

hela-petereit@

medizin.uni-koeln.de

Received 23 October 2000 and in revised form

16 March 2001

Accepted 9 April 2001 great importance as they may lead to bacterial meningitis, which is a life threatening disease with a mortality rate of $25 \%-50 \%$. About $20 \%$ of cases of bacterial meningitis are due to a CSF leak. ${ }^{1}$ Fistulas leaking CSF are sequelae of skull fractures or surgical procedures at the anterior or middle cranial fossa, the nasal sinus, or the temporal bone. Their frequency after temporal bone fracture was found to be $15 \%{ }^{2}$ The aetiology of liquorrhoea remains obscure in up to $39 \%$ of cases, including those with spontaneous liquorrhoea. ${ }^{3}$ Rare conditions leading to fistulas leaking CSF are intracranial hypertension, sphenoidal sinusitis, bromocriptine therapy of macroprolactinoma, and malformations of the inner ear. ${ }^{4-7}$ Such fistulas should be suspected in patients presenting with intermittent or permanent water-like secretion of the nose or-to a lesser extent-of the ear, which may be confounded with rhinitis or otitis. In some patients, orthostatic headache may be present as well. The first aim of the diagnostic procedures is to prove the presence of CSF in a given sample. The second step is the location of the fistula using either high resolution CT, CT cisternography, MRI, endoscopy, or detection of radioactive tracer or fluorescein dye previously injected into the lumbar subarachnoidal space. ${ }^{8}$ In a third step the dural defect has to be closed by surgery.

Felgenhauer et al demonstrated that an ideal marker for liquorrhoea should be present in normal CSF but not in other body fluids and should be detectable rapidly with routine laboratory methods. ${ }^{9} \beta$-Trace protein was introduced by Felgenhauer et al as a marker for liquorrhoea because its concentration in normal CSF is 35 -fold higher than in serum. The protein is absent in tear fluid or nasal secretion. This protein belongs to the lipocalin family, a group of carrier proteins with enzymatic function. After determination of its amino acid sequence, it became evident that $\beta$-trace protein is identical with prostaglandin D-synthase..$^{10}$ The physiological role of $\beta$-trace protein, which is produced in the meninges, the choroid plexus, and to a lesser extent in astrocytes, is not known. ${ }^{11-13}$ Animal experiments point to a role in sleep regulation and nociception. ${ }^{14}{ }^{15} \beta$-Trace protein in CSF has been studied in various CNS diseases but is of limited value except for the differential diagnosis of blood-brain barrier disturbances. ${ }^{16-21} \mathrm{By}$ contrast, $\beta$-trace protein electroimmunoassay is an important tool with a sensitivity of $97 \%$ and specificity of $100 \%$ in the diagnosis of fistulas leaking CSF. ${ }^{92}$ Here we present a study of 140 liquid samples suspected of containing CSF which were investigated for $\beta$-trace protein using a new nephelometric assay.

\section{Methods}

SAMPLES

Samples (140) from 100 patients from neurological (9\%), neurosurgical $(19 \%)$, otolaryngological $(57 \%)$, and other $(15 \%)$ departments with clinically suspected liquorrhoea were collected during 2 years and investigated with electroimmunoassay and nephelometric assay. Sampling of ear or nose secretion, ear or nose tamponades, intraoperative secretion suspected of containing CSF, or postoperative 


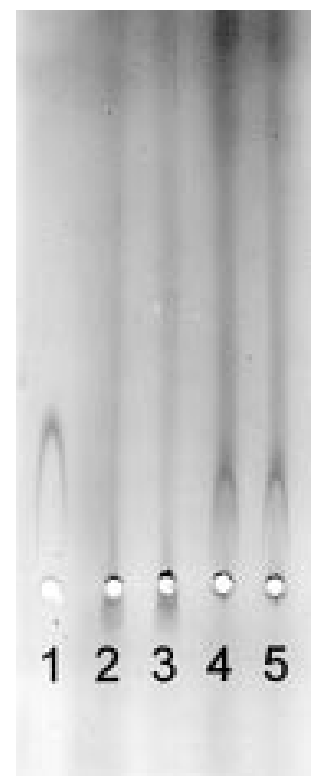

Figure 1

Electroimmunoassay for $\beta$-trace protein. 1: positive control (CSF); 2 and 3. negative control (serum); 4 and 5: positive samples (nasal secretion). hygroma was performed. Sensitivity and specificity of the nephelometric assay were calculated referring to the electroimmunoassay results.

Additionally, the clinical records of 79 of the 140 samples were reviewed for radiological or surgical findings indicating fistulas and compared with the results of the $\beta$-trace protein assay. These 79 samples were from 52 patients, 32 men and 20 women, with a mean age of 48 years and a range between 8 and 85 years. All patients had a serum creatinine within the normal range.

Twenty CSF samples of patients presenting with tension headache who showed a normal CSF analysis were analysed for $\beta$-trace protein, as well as serum samples from 34 normal volunteers. The mean age (SD) of the 20 patients was 45 (15.8) years. The mean cell count was 1 (SD 0.9)/ $\mu$ l and the mean serum/ CSF albumin ratio was 223.9 (SD 84.3).

\section{$\beta$-TRACE PROTEIN ELECTROIMMUNOASSAY}

Anti-human $\beta$-trace protein antibody production was induced in rabbits ${ }^{9}$ and detection of $\beta$-trace protein was performed by electroimmunoassay as described previously. ${ }^{23}$ Briefly, Gelbond plates (Sigma, Munich, Germany) were coated with gel containing $1.5 \%$ Litex agarose (Litex, Denmark), 1\% polyethylene glycol 6000 (Merck, Darmstadt, Germany), $0.02 \mathrm{M}$ barbital buffer $\mathrm{pH} 8.6$, and $1 \%$ antibody; $5 \mu$ of sample and a positive and negative control were placed in preformed holes. Samples of CSF served as positive controls, serum samples as negative controls. Electrophoresis was performed with a $0.02 \mathrm{M}$ barbital buffer $\mathrm{pH} 8.6$ for 3 hours at $4^{\circ} \mathrm{C}$ and $250 \mathrm{~V}$. Complexes of $\beta$-trace protein and its antibodies were detected by $0.5 \%$ Coomassie blue (Serva Heidelberg, Germany). The detection limit of the method is $5 \mathrm{mg} / \mathrm{l}$. A sample was juged as positive if $\beta$-trace protein-protein antibody complexes were present in the typical rocket formation (fig 1 ).

\section{$\beta$-TRACE PROTEIN NEPHELOMETRIC ASSAY}

For determination of $\beta$-trace protein a newly developed nephelometric research assay (N latex $\beta T P$ ) was used. $\mathrm{N}$ Latex $\beta \mathrm{TP}$ (Dade Behring, Marburg Germany) is a lyophilised reagent for Behring nephelometer (BN) systems. It contains polystyrene particles coated with immunoaffinity purified polyclonal antibodies from rabbits against human $\beta$-trace protein, which are agglutinated in the presence of $\beta$-trace protein. The increase in light scattering caused by agglutination is measured by the $\mathrm{BN}$.

Samples $(5 \mu \mathrm{l})$ are diluted to a total volume of $500 \mu \mathrm{l}$ with diluens buffer (Dade Behring, Marburg, Germany) and measured on a nephelometer. Twelve minutes after addition of $\mathrm{N}$ latex $\beta \mathrm{TP}$ light scattering is measured again. The reaction kit consists of $50 \mu$ polystyrene particles coated with $1.8 \mathrm{mg} / 100 \mathrm{mg}$ immunoaffinity purified polyclonal rabbit antihuman $\beta$-trace protein antibodies, $15 \mu \mathrm{l}$

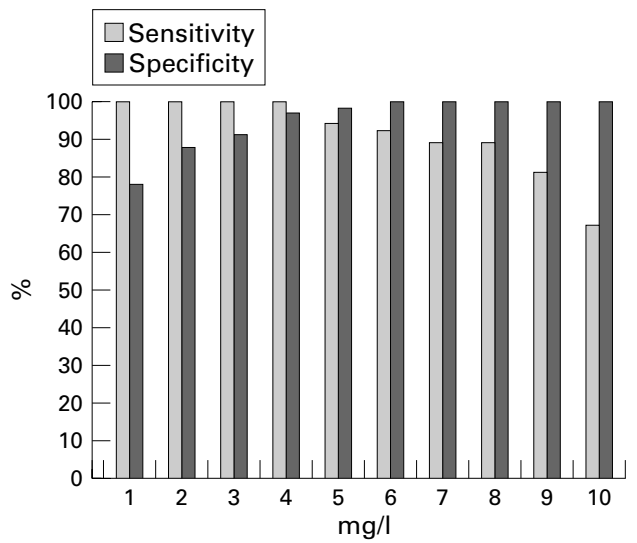

Figure 2 Sensitivity and specificity of $\beta$-trace protein nephelometric assay in comparison with the electroimmunoassay for 10 critical concentrations of $\beta$-trace protein.

supplement to avoid interference with antiIgG-antibodies (Dade Behring, Marburg, Germany), and diluens buffer. The concentration of $\beta$-trace protein is calculated by the $\mathrm{BN}$ software using a seven point standard curve prepared automatically from a single calibrator containing native human $\beta$-trace protein. Standardisation of the N Latex $\beta \mathrm{TP}$ assay is based on highly purified $\beta$-trace protein from CSF characterised by amino acid sequencing and quantified by quantitative amino assay analysis. The measuring range is 0.25 to 15.8 $\mathrm{mg} / \mathrm{l}$ for the original dilution of 1:100. Samples with higher or lower $\beta$-trace content are automatically measured again with an appropriate dilution. The detection limit for a $1: 1$ diluted sample is $2.5 \mu \mathrm{g} / \mathrm{l}$. The analytical imprecision of the assay is $2.3 \%-6.5 \%$.

\section{STATISTICS}

To validate the nephelometric assay for $\beta$-trace protein in the diagnosis of liquorrhoea the well established electroimmunoassay was used as an external validation criterion. The reference method is coded in the form of a dichotomous variable with the possible outcome 1 (negative) and 2 (positive). The tested method is a continuos variable with a minimum score of 0.2 and a maximum score of $53.9 \mathrm{mg} / 1$. Because the emphasis is on avoiding false positive predictions the critical value for the nephelometric assay was determined for the specificity which reaches $100 \%$. Accordingly, $2 \times 2$ contingency tables were determined for 10 different versions of a dichotomised nephelometric variable. The nephelometric $\beta$-trace protein value was recoded to 1 (negative) and 2 (positive) by varying the critical value for a negative diagnosis from $1 \mathrm{mg} / 1$ to $10 \mathrm{mg} / 1$. Sensitivity and specificity for each critical value are summarised in figure 2. Additionally, $\chi^{2}$ tests (or Fisher's exact tests) were applied to test for statistical significance of the relation between the two methods.

\section{Results}

ELECTROIMMUNOASSAY AS REFERENCE METHOD Of 140 samples of clinically suspected liquorrhoea, 36 were found to be positive for $\beta$-trace protein detected by electroimmunoassay. The 
Table 1 Clinical characteristics of patients with CSF leak. The diagnostic procedures that proved the diagnosis are given in bold

\begin{tabular}{|c|c|c|c|c|c|c|}
\hline $\begin{array}{l}\text { Patient } \\
\text { No }\end{array}$ & $\begin{array}{l}\text { Age } \\
(y)\end{array}$ & Sex & Aetiology of CSF leak & Diagnostic procedures & $\begin{array}{l}\text { Observation } \\
\text { period } \\
\text { (months) }\end{array}$ & Complications \\
\hline 1 & 68 & Female & Unknown & CT, scintigraphy & 2 & None \\
\hline 2 & 8 & Female & Post-traumatic & $\begin{array}{l}\text { CT, cisternography, intrathecal fluorescein, } \\
\text { endoscopic surgery }\end{array}$ & 5 & None \\
\hline 3 & 58 & Male & Sinusitis sphenoidalis & CT, surgery & 0 & Meningitis, exitus \\
\hline 4 & 73 & Male & After craniotomy & CT, surgery & 7 & Meningitis \\
\hline 5 & 72 & Female & After ventriculotomy & CT & 31 & None \\
\hline 6 & 83 & Male & $\begin{array}{l}\text { Frontobasal } \\
\text { meningioma }\end{array}$ & CT, surgery & 1,5 & None \\
\hline 7 & 58 & Female & Unknown & CT & 32 & None \\
\hline 8 & 57 & Male & Post-traumatic & CT, surgery & 37 & None \\
\hline 9 & 46 & Male & After craniotomy & CT, surgery & 38 & None \\
\hline 10 & 19 & Male & Frontobasal fracture & $\begin{array}{l}\text { CT, MRT, intrathecal fluorescein, endoscopic } \\
\text { surgery }\end{array}$ & 40 & $\begin{array}{l}\text { Recurrence which led to revision } \\
\text { surgery, none }\end{array}$ \\
\hline
\end{tabular}

nephelometric assay for $\beta$-trace protein showed 33 positive samples. None of the electroimmunoassay negative samples was positive in the nephelometric assay. Under the premise of a low rate of falsely positively predicted cases (a specificity of $100 \%$ ) the critical value of the nephelometric assay could be quantified with 6 $\mathrm{mg} / \mathrm{l}$ or more of protein. If sensitivity was considered simultaneously, the critical value of 6 $\mathrm{mg} / \mathrm{l}$ was the best choice leading to a sensitivity of $92 \%$. The relation between the electroimmunoassay and the nephelometric assay was highly significant in any chosen critical value $(\mathrm{p}<0.001)$.

CLINICAL EVALUATION AS A REFERENCE METHOD In the group of 52 patients (79 samples), 13 samples from 10 patients were positive for $\beta$-trace protein with both methods. In three patients measurements were repeated. In one patient two positive results in two samples were found and in another patient three positive results in five samples were found. The two negative samples of this patient were taken after successful closure of a CSF leak. In the third patient - a child of 8 years with a combined temporal bone and sphenoid sinus fracturethe first sample taken from the nose was positive for $\beta$-trace protein. Therefore endoscopic sinus surgery was performed with closure of the sphenoid fracture line. Two postoperative controls from nasal secretion were negative. When the patient developed a bacterial meningitis 8 months later, a sample of nasal secretion was taken and was found negative for $\beta$-trace protein. Cranial CT showed signs of fluid in the mastoid cells at the side of the temporal bone fracture. An explorative mastoidectomy and tympanoscopy was performed which showed a dural prolapse with a clear CSF leak. The defect was closed the next day by a temporal approach. It is possible that the nasal secretion from the anterior parts of the nose did not contain any CSF as this time the CSF fistula was located temporally. Although the negative result of this $\beta$-trace analysis was due more to inadequate sampling than lack of sensitivity of the method, we judged this analysis as a false negative result. This evaluation gave a sensitivity of $93 \%$ for the nephelometric $\beta$-trace assay.

In all 10 patients, the clinically suspected liquorrhoea and the positive $\beta$-trace protein result could be confirmed by other techniques.

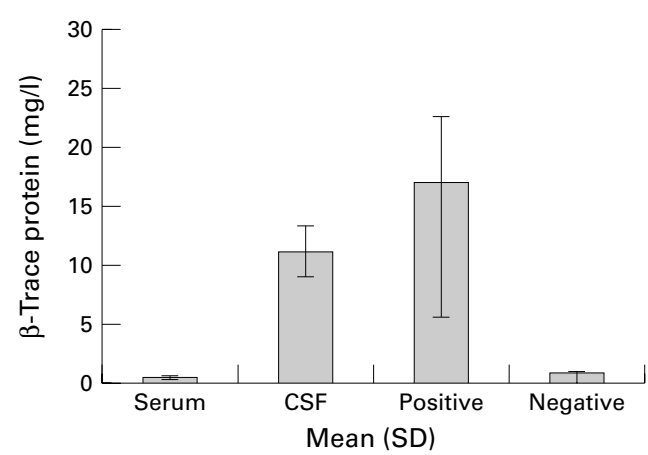

Figure 3 Mean (SD) of $\beta$-trace protein concentrations in serum and CSF of patients with tension headache: negative and positive samples.

Table 2 Mean values ( $m g / l)$ for serum and CSF $\beta$-trace protein measured by nephelometry

\begin{tabular}{lll}
\hline First author & Serum $\beta$-trace protein & CSF $\beta$-trace protein \\
\hline Felgenhauer $^{31}$ & 0.5 & 17 \\
Tumani $^{16}$ & 0.5 & 15 \\
Own results & 0.5 & 11 \\
\hline
\end{tabular}

Table 1 shows the investigations that were performed in the $10 \beta$-trace positive patients. The diagnosis of a CSF leak was proved by CT in seven, by surgical inspection in six, and in one patient by cisternography and intrathecal fluorescein application.

All other samples were negative in the nephelometric and electroimmunoassay.

In none of the $\beta$-trace negative patients was a liquorrhoea shown by any imaging technique used or by surgery. Computed tomography was used in $99 \%$, surgical inspection in $49 \%$, MRI in $13 \%$, radionuclide imaging of the subarrachnoid space in $3 \%$, and intrathecal fluorescein application in $1 \%$ of $\beta$-trace protein negative cases. This gave a specificity of $\beta$-trace protein detection in the diagnosis of liquorrhoea of $100 \%$.

The mean $\beta$-trace protein concentrations measured with the nephelometric assay in serum of 34 healthy volunteers, CSF of 20 patients with tension headache, 107 negative, and 33 positive samples are summarised in figure 3.

Table 2 gives an overview from the literature of mean values for serum and CSF $\beta$-trace protein measured by nephelometry.

\section{Discussion}

Our results indicate a high sensitivity and specificity of the nephelometric $\beta$-trace protein 
assay in diagnosing liquorrhoea. This accords with previous findings of a sensitivity of $97.3 \%$ and a specificity near $100 \%$ using the electroimmunoassay in 101 patients. $^{22}$ In this study, comparison with the established electroimmunoassay gave a sensitivity of $92 \%$ and a specificity of $100 \%$. This was confirmed be the clinical validation, which showed a sensitivity of $93 \%$ and a specificity of $100 \%$.

The introduction of the nephelometric assay is a substantial improvement in $\beta$-trace protein detection as the method is highly automated; this results in a shorter analysis time of 15 minutes. By comparison, the electroimmunoassay method needs about 3 to 4 hours for the same result. As mentioned above, the rapid diagnosis of liquorrhoea is essential for some physicians, including neurologists, neurosurgeons, and otorhinolaryngologists. Once the diagnosis of liquorrhoea is proved, any effort, including invasive diagnostic procedures or explorative surgery, should be undertaken to localise the site of the leak and to close it before a life threatening meningitis might occur.

From the technical point of view, the nephelometric assay for $\beta$-trace protein can be performed with very small amounts of sample ( $5 \mu \mathrm{l}$ are recommended) and is easy to carry out with routine laboratory equipment. False positive results may occur in patients with renal failure who have increased serum $\beta$-trace protein concentrations. ${ }^{24}$ False negative results may occur when contamination is limited $(<5 \%) .{ }^{25}$ As $10 \%$ to $30 \%$ of $\beta$-trace protein in a sample are bound by gauze swabs, inappropriate sampling may also result in false negative results. ${ }^{25}$

In our series, the results of $\beta$-trace protein measurement in serum and CSF in the control group are in line with previous results. ${ }^{16}$ Whereas the serum values were identical with those given in the literature, the CSF values were slightly lower, which might be explained by the lower age and serum/CSF albumin ratio in our control group. The samples negative for $\beta$-trace protein showed low mean $\beta$-trace protein concentrations, comparable with those measured in the serum of the control group (fig 3 ). The positive samples showed mean $\beta$-trace protein concentrations that were expected for CSF. In a few samples, $\beta$-trace protein concentration was unexpectedly high. Together with the broad range of the SD in the group of positive samples, this might reflect the various methods of sampling. These will result in a dilution of the sample containing CSF by other body fluids in most of the cases, but may lead to a higher concentration of the CSF within the sample in isolated cases as well.

Other CSF specific proteins, such as $\beta_{2}-$ transferrin, have been suggested as indicators of liquorrhoea. ${ }^{26}$ However, compared with $\beta$-trace protein, the clinical evaluation of $\beta_{2}$ transferrin showed it to have lower sensitivity and specificity. In early studies, a sensitivity of $79 \%$ was found. ${ }^{26}$ Other findings report a higher sensitivity, of nearly $100 \%$, but a reduced specificity of $95 \% .{ }^{27}$ Reasons for a falsely positive $\beta_{2}$-transferrin test are underlying hepatic diseases with $\beta_{2}$-transferrin being detectable in the serum, also, and allelic variants of the serum transferrin that cannot be distinguished from $\beta_{2}$-transferrin by the electroimmunoassay. ${ }^{28}{ }^{29} \mathrm{~A}$ further disadvantage of $\beta_{2}$-transferrin assay is that it is time consuming; it takes 3.5 hours even in its latest improved version. ${ }^{30}$

A historical marker of liquorrhoeaglucose-has not been considered as it is present abundantly in serum and blood. Even in water-like secretions from the nose or ear it is of limited use as reference values have not yet been established and data on sensitivity and specificity of the method are lacking.

In conclusion nephelometric $\beta$-trace protein detection is rapid and highly valid for the diagnosis of a CSF leak and should help to facilitate the management of patients with suspected liquorrhoea.

1 Durand ML, Calderwood SB, Weber DJ, et al. Acute bacterial meningitis in adults. A review of 493 episodes. $N$ Engl F Med 1993;328:21-8.

2 Brodie HA, Thompson TC. Management of complications from 820 temporal bone fractures. Am f Otol 1997;18:18897.

3 Ramsden JD, Corbridge R, Bates G. Bilateral cerebrospinal fluid rhinorrhoea. F Laryng Otol 2000;114:137-8.

4 Clark D, Bullock P, Hui T, et al. Benign intracranial hypertension: a cause of CSF rhinorrhoea. 7 Neurol Neurosurg Psychiatry. 1994;57:847-9.

5 Xenos C, Rosenfeld JV, Kleid SM. Intracranial extension of sphenoid sinusitis. Head Neck 1995;17:346-50.

6 Barlas O, Bayindir C, Hepgul K, et al. Bromocriptininduced cerebrospinal fluid fistula in patients with induced cerebrospinal fluid fistula in patients with macroprolactinomas: report of three cases

7 Graham JM, Phelps PD, Michaels L. Congenital malformations of the ear and cochlear implantation in children: review and temporal bone report of common cavity. $f$ Laryngol Otol Suppl 2000;25:1-14

8 Byrne JV, Ingram CE, MacVicar D, et al. Digital subtraction cisternography: a new approach to fistula localisation in cerebrospinal fluid rhinorrhoea. $\mathcal{F}$ Neurol Neurosurg Psychiatry 1990;53:1072-5.

9 Felgenhauer K, Schädlich HJ, Nekic $M$. $\beta$-trace protein as marker for cerebrospinal fluid fistula. Klin Wochenschr 1987;65:764-8

10 Hoffmann A, Conradt HS, Gross G, et al. Purification and chemical characterization of $\beta$-trace protein from human cerebrospinal fluid: its identification as prostaglandin D synthase. ₹ Neurochem 1993;61:451-6.

11 Blödorn B, Bruck W, Tumani H, et al. Expression of the $\beta$-trace protein in human pachymeninx as revealed by in $\beta$-trace protein in human pachymeninx as revealed by in
situ hybridization and immunocytochemistry. $\mathcal{f}$ Neurosci Res 1999;57:730-4.

12 Blödorn B, Mäder M, Urade Y, et al. Choroid plexus: the major site of mRNA expression for the $\beta$-trace protein (prostaglandin D synthase) in human brain. Neurosci Lett 1996;209:117-120.

13 Giacomelli S, Leone MG, Grima J, et al. Astrocytes synthesize and secrete prostaglandin D synthetase in vitro. Biochim Biosphys Acta 1996;1310:269-76.

14 Urade Y, Hayaishi O. Prostaglandin D2 and sleep regulation. Biochim Biophys Acta 1999;1436:606-15.

15 Eguchi N, Minami T, Shirafuji N, et al. Lack of tactile pain (allodynia) in lipocalin-type prostaglandin D synthasedeficient mice. Proc Natl Acad Sci USA 1999;96:726-30.

16 Tumani $H$, Nau R, Felgenhauer $K$. $\beta$-trace protein in cerebrospinal fluid: a blood-CSF-related evaluation in neurological diseases. Ann Neurol 1998;44:882-9.

17 Tumani H, Reiber H, Nau R, et al. $\beta$-trace protein concentration in cerebrospinal fluid is decreased in patients with tration in cerebrospinal fluid is decreased in patien

18 Saso L, Leone MG, Sorrentino C, et al. Quantification of prostataglandin D synthase in cerebrospinal fluid: a potenprostataglandin D synthase in cerebrospinal fluid: a poten643-56.

19 Melegos DN, Freedman MS, Diamandis EP. Prostaglandin D synthase concentrations in cerebrospinal fluid and serum of patients with neurological disorders. Prostaglandins 1997;54:463-74.

20 Mase M, Yamada K, Iwata A, et al. Acute and transient increase of lipocalin-type prostaglandin D synthase ( $\beta$ trace) level in cerebrospinal fluid of patients with aneurysmal subarachnoid hemorrhage. Neurosci Lett 1999;270: $188-90$

21 Grunewald S, Huyben K, de Jong JG, et al. $\beta$-trace protein in human cerebrospinal fluid: a diagnostic marker for $\mathrm{N}$-glycosylation defects in brain. Biochim Biophys Acta 1999;1455:54-60.

22 Bachmann G, Achtelik R, Nekic $M$, et al. Clinical experience with $\beta$-trace protein as a marker for cerebrospinal fluid fistula. HNO 2000;48:496-500.

23 Laurell CB. Electroimmunoassay. Scand $\mathcal{F}$ Clin Lab Invest 1972;29(suppl 124):21-3. 
24 Melegos DN, Grass L, Pierratos A, et al. Highly elevated levels of prostaglandin D synthase in the serum of patients .

25 Kleine TO, Damm T, Althaus H. Quantification of $\beta$-trace protein and detection of transferrin isoforms in mixtures of cerebrospinal fluid and blood serum as models of rhinorrhea and otorrhea diagnosis. Fresenius fournal of Analytical Chemistry;366:382-6.

26 Oberascher G, Arrer E. Immunologische Liquordiagnostik mittels $\beta_{2}$-Transferrin. Grundlagen und Methodik. Laryngology Rhinologie Otologie 1986;65:158-61.

27 Skedros DG, Cass SP, Hirsch BE, et al. $\beta-2$ transferrin assay in clinical management of cerebro spinal fluid and perilymphatic fluid leaks. Otolaryngol 1993;22:341-4.
28 Thalmann I, Kohut RI, Ryu J, et al. Protein profile of human perilymph in search of markers of the diagnosis of perilymph in search of markers of the diagnosis of perilymph fistula and other inner ear disease. Otolaryngol Purg 1994;111:273-80.

29 Sloman AJ, Kelly RH. Transferrin allelic variants may cause false positives in the detection of cerebrospinal fluid fistula. Clin Chem 1993;39:1444-5.

30 Normansell DE, Stacy EK, Booker CF, et al. Detection of $\beta-2$ transferrin in otorrhea and rhinorrhea in a routine clinical laboratory setting. Clin Diagn Lab Immunol 1994;1: 68-70.

31 Felgenhauer K, Beuche W. Liquorproteine lokalen Ursprungs. In: Labordiagnostik neurologischer Erkrankungen. Stuttgart, New York: Thieme Verlag, 1999:14.

\section{HISTORICAL NOTE}

\section{Ammon's horn and the hippocampus}

The word hippocampus comes from late Latin: hippocampus, derived from the Greek words for a horse+sea monster. In mythology it was a sea horse, having two forefeet, with the body ending in a dolphin's or fish's tail, represented as drawing the vehicle of Neptune the sea God. The earliest use (Oxford English Dictionary) was in 1606, cited as "Drummond of Hawthornden" Let. Wks. (1711) 232. "Stately pageants. that of Cheapside was of Neptune on a hippocampus, with his Tritons and Nêreides".

Neurologists recognise it as each of two elongated eminences (hippocampus major and minor) on the floor of each lateral ventricle of the brain; so called from their supposed resemblance to the fish.

With its base in ancient classical history, neuroanatomy provides several metaphors that relate the gods and the brain. One is Ammon's horn. The term Cornu Ammonis, or
Ammon's horn, is a well known description of the whorled chambered shells of a fossil genus of Cephalopods. They were once supposed to be coiled snakes petrified, and hence called "snake-stones" from their resemblance to the involuted horn of Jupiter Ammon.

The hippocampus received its name from the Italian Julius Caesar Arantius in the late 16th century. ${ }^{1}$ Less than two centuries later, the hippocampus was called Ammon's horn. ${ }^{23}$ An early, anatomical use is in the 1742 book of a felicitously named surgeon René Jacques Croissant de Garengeot. ${ }^{4}$ In 1732 Jacques Bénigne Winslow used the term ram's horn. Thus Ammon's horn was probably not in use at this date. Albrecht von Haller, the anatomist, indicated that the term Ammon's horn was already used in a paper of the Oeconomische Abhandlung of 1755 (Haller, 1774-7, vol 2 p 507).

The term Ammon's horn is a metaphor that refers to the ram shaped horns $\mathrm{s}^{5}$ on the head representing the Egyptian God Amun who protected the Pharaoh Taharqa in the temple of Kawa. ${ }^{6}$ Many temples were dedicated to Amun. The Greek form of the name was Ammon, the Libyan Jupiter whom the Greeks identified with Zeus. King David conquered a Jordanian tribe, the Ammonites, who were descendants of Lot, by the son of his younger daughter.

It is of interest that the related hippocampal commissure together with the crura of the fornix, is sometimes termed the "psalterium" or "lyra Davidis". Psalterium and lyra are both harps.

To add to the confusion, French neuroanatomists refer to the horn shaped lateral part of the fourth ventricle with its choroid plexus leaving the foramen like a posy of flowers as the "corne d'abondance" (horn of plenty, or cornucopia).

J M S PEARCE

304 Beverly Road, Anlaby, Hull HU10 7BG, UK

jmspearce@freenet.co.uk

1 Olry R, Haines DE. Cerebral mythology: a skull stuffed with gods. Fournal of the History of the Neurosciences 1998;7:82-3.

2 Lewis FT. The significance of the term hippocampus. F Comp Neurol 1922-3;35:213-30

3 Olry R, Fischer A. The limbic terminology; natural history of demantic fluctuations. Acta Belg Hist Med 1993;6:220-3.

4 Garengeot RJ, Croissant de. Splanchnologie ov l'Anatomie des viscères (cited byOlry and Haines ${ }^{1}$ ).

5 Winslow JB. Exposition anatomique de la structure du corps humain (cited by Olry and Haines ${ }^{1}$ ).

6 De Smet Y. De l'hippocampe à la corne d'Ammon. Histoire Anatomie, Embryologie. Louvain, UCB Pharma, 1995. 